University of Wollongong

Research Online

Faculty of Engineering and Information

Faculty of Engineering and Information

Sciences - Papers: Part A

Sciences

1994

\title{
The interpretation of laser sensing measurements for blast furnace operations and control
}

\author{
Peter C. Wall \\ BHP Steel Group \\ R J Turner \\ BHP Steel Group \\ Mark Hughes \\ BHP Steel Group \\ Peter Huk \\ BHP Steel Group \\ Ross J. Haywood \\ BHP Steel Group
}

See next page for additional authors

Follow this and additional works at: https://ro.uow.edu.au/eispapers

Part of the Engineering Commons, and the Science and Technology Studies Commons

Research Online is the open access institutional repository for the University of Wollongong. For further information contact the UOW Library: research-pubs@uow.edu.au 


\title{
The interpretation of laser sensing measurements for blast furnace operations and control
}

\author{
Abstract \\ Several laser-based sensors for use on blast furnaces have been developed and implemented, including a \\ raceway sensor, burden level sensor (single point) and burden surface profiler. These sensors are based \\ on the time-of-flight technique and give high levels of accuracy in all applications. The data obtained from \\ the sensors during normal furnace operations are examined in light of the process models utilised by \\ operators and for the interpretation of pulverised coal injection performance. Raceway sensory data \\ obtained during a furnace blow-in are also discussed. \\ Keywords \\ interpretation, measurements, laser, blast, furnace, operations, control, sensing \\ Disciplines \\ Engineering | Science and Technology Studies

\section{Publication Details} \\ Wall, P. C., Turner, R. J., Hughes, M., Huk, P., Haywood, R. J., McCarthy, M. J. \& Zulli, P. (1994). The \\ interpretation of laser sensing measurements for blast furnace operations and control. Revue de \\ Metallurgie, 91 (3), 411-420.
}

\section{Authors}

Peter C. Wall, R J Turner, Mark Hughes, Peter Huk, Ross J. Haywood, M J McCarthy, and Paul Zulli 
P.C. Wall, R.J. Turner, M. Hughes, P. Huk, R.J. Haywood, M.J. McCarthy, P. Zulli (BHP Steel Group, Australia)

\section{INTRODUCTION}

Over the last seven years, BHP has developed and implemented several laser-based sensors for use on its blast furnaces, including a raceway sensor, burden level sensor (single point) and burden surface profiler. The driving forces behind these developments relate to operator requirements of monitoring the furnace condition in a non-invasive manner and providing accurate data for control of burden distribution, peripheral gas distribution and stock level, and for associated process models. Laser range finding techniques offer the following advantages : fewer entry ports to the furnace, remote operations and improved accuracy.

This paper provides a brief review of the developments in laser-based sensing, together with a detailed examination of the data obtained during furnace operations. An analysis of the data with respect to both normal and abnormal (e.g. furnace blow-ins) operations is discussed. A future application of the raceway sensor for pulverised coal combustion studies in the blast furnace is also described.

\section{- LASER-BASED SENSORS}

Robert TURNER, 36 ans, chercheur scientifique. Responsable du développement de l'équipement de détection de BHP, travaillant dans la section des technologies d'habilitation au département Recherche de BHP.

Mark HUGHES, 31 ans, ingénieur développement. Responsable de la mise en place des techniques de détection dans les hautslourneaux de l'usine de Newcastle.

Peter HUK, 34 ans ingénieur développement. Responsable de la mise en place de l'équipement de détection dans les hautslourneaux de Port Kembla.

Ross HAYWOOD, 33 ans, docteur en génie mécanique. Responsable des ćtudes sur l'injection de charbon pulvérisé et de lit modélisation des hauts-fourneaux dans la section de traitement des minéraux du département Recherche de BHP.

Malcolm McCARTHY, 53 ans, docteur en génie chimique. Responsable de l'ensemble des recherches sur les hauts-fourneaux. comprenant l'injection de charbon pulvérisé et les programmes de prolongation de durée de vie dans la section de traitement des minéraux au département Recherche de BHP.

Paul ZULLI, docteur en génie chimique. Coordinateur des recherches sur l'élaboration de la fonte dans la section de traitement des minéraux au département Recherche de BHP, responsable de l'ensemble de la recherche pour l'élaboration de la fonte classique

* Subject of lecture at the ATS Steelmaking Conference 1993 (Paris. 15\%6 December. 1993. Session 3).

\section{Principle of operation.}

The basic operating principle of all the laser systems employed is that of time-of-flight (TOF) laser ranging, as illustrated in figure 1 . This technique uses the time taken for a short pulse of light to travel from a laser source to a target and back to a detector. The range, $\mathrm{R}$, is calculated using the equation shown in figure 1 , where $\mathrm{C}$ is the velocity of light, $t$ is the time taken for pulse to travel from source to detector and $\mathrm{n}$ is the refractive index of the fluid medium. Although the technique is relatively straightforward, sophisticated signal processing is required to extract the range information from the raw data.

\section{Location of sensors on blast furnace.}

Figure 2 shows the positions of the three sensors on the blast furnace. The burden level sensor (single point) or laser stockrod is used on Newcastle No. 3 blast furnace (bell-top) as a backup for an existing mechanical stockrod, since the configuration of the furnace top does not permit the installation of another mechanical-type stockrod. The 


\section{Interprétation des mesures par capteur laser au haut-fourneau}

\author{
P.C. Wall, R.J. Turner, M. Hughes, P. Huk, \\ R.J. Haywood, M.J. McCarthy, P. Zulli \\ (BHP Steel Group, Australie)
}

Ces sept dernières années, BHP a installé et exploité sur ses hauts-fourneaux plusieurs sondes ou capteurs basés sur le rayonnement laser dont une sonde de niveau optique, un profilomètre au gueulard et une sonde de zone tourbillonnaire. L'impulsion donnée à ces développements provient $d u$ besoin de surveiller la marche du haut-fourneau d'une manière non gênante en fournissant des données précises sur la répartition de la charge et du gaz périphérique et sur le niveau de chargement ainsi que pour des modèles associés de procédés.

Le principe opératoire de base de chaque capteur est la technique du temps de trajet laser pour mesurer les distances. Cette technique est fondée sur le temps nécessaire à une petite impulsion photonique pour aller d'une source laser à une cible et pour revenir à un détecteur.

Une analyse des résultats obtenus avec le profilomètre de surface de charge du haut-fourneau $n^{\circ} 4$ de Newcastle et une comparaison avec les prévisions de répartition de charge données par les modèles de process ont montré que les données pouvaient être utilisées pour vérifier ou ajuster les paramètres de trajectoire des matériaux. Les effets des paramètres de modification des trajectoires sur les prévisions du modèle en ce qui concerne la zone de fusion se sont révélés importants.

Les profondeurs de zone tourbillonnaire mesurées par les capteurs de zone tourbillonnaire ont été validées à l'aide d'une sonde mécanique insérée dans la tuyère d'une haut-fourneau en service. La corrélation entre les profondeurs mesurées par la sonde et par le capteur de zone tourbillonnaire a été excellente. La mesure de la profondeur de la zone tourbillonnaire a montré que le débit de vent chaud du haut-fourneau $n^{\circ} 4$ de Newcastle était réparti de façon non uniforme, surtout à cause de l'aménagement de la conduite principale d'entrée de vent chaud par rapport aux trous de coulée et à l'effet des niveaux du liquide de creuset. Des profondeurs plus grandes ont été mesurées à proximité du trou de coulée (exactement $1,1 \mathrm{~m}$ ) en comparaison avec celles mesurées à proximité de l'entrée du vent (exactement $0,7 \mathrm{~m}$ ).
Le capteur de zone tourbillonnaire a été utilisé dans deux autres applications. D'abord dans un fourneau à injection de charbon pulvérisé (PCI) où l'on a déterminé la faisabilité de l'instrumentation du pilotage de l'injection de charbon pulvérisé et la fourniture d'information au sujet de la combustion du charbon pulvérisé pour une série de conditions de fonctionnement du hautfourneau. Une variation spatiale de la série des données obtenues fournit d'utiles informations pour l'optimisation de la combustion du charbon pulvérisé. En second lieu, pendant la mise à feu du fourneau, là où la séquence d'ouverture des tuyères devait être optimisée. Il est évident que cette information sur la profondeur et sur la brillance pourrait être utilisée pour réduire le temps total nécessaire pour ouvrir les tuyères (c'est-àdire le temps nécessaire pour la reprise de la production complète) et pour indiquer les conditions opératoires qui risquent d'être dangereuses telles que le drainage insuffisant des liquides de la zone tourbillonnaire. Un autre aspect utile de cet essai concerne l'observation des chutes en marche qui ont été détectées dans le niveau du rapport de brillance 5 à 10 minutes avant la chute.

Une future application du capteur de zone tourbillonnaire pour les études de la combustion du charbon injecté dans le haut-fourneau est également décrite. 


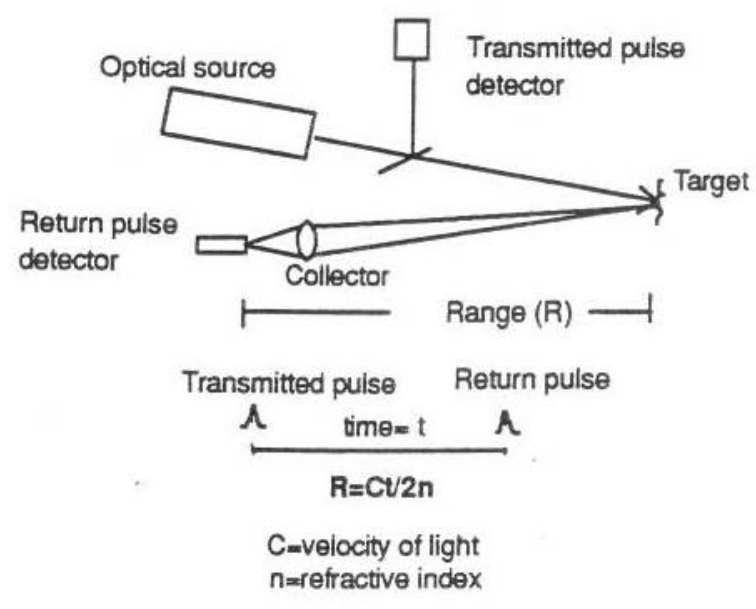

Fig. 1 - Time of flight principle.

Fig. 1 - Principe du temps de trajet

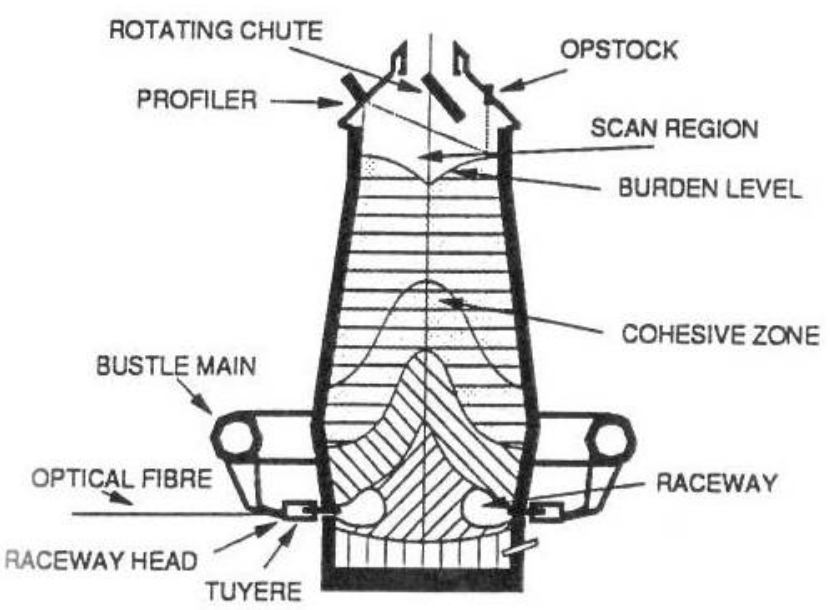

Fig. 2 - Location of sensors on blast furnace.

Fig. 2 - Position des capteurs dans le haut-fourneau.

sensor measures the distance to a single point on the burden surface and allows the direct measurement of filling level, including «out-of-reach» burden, and indirectly, the burden descent rate.

The burden surface profiler (profiler) is a single unit system and measures the burden level and surface temperature distribution over the entire cross-section of the furnace. Following the installation and successful trial of a prototype version, a ruggedised, industrial model will be installed in early 1994 on Newcastle No. 4 blast furnace (NBF4).

The laser raceway sensor measures the raceway depth and dual wavelength brightness ratio and is still a prototype. To date, up to four sensors have been used simultaneously on a blast furnace (NBF4, Whyalla No. 2 blast furnace and Nakayama No. 2 blast furnace (Japan), the latter furnace using pulverised coal injection). A detailed discussion of the profiler and raceway sensor follows.

\section{Laser profiler.}

The profiler system consists of a scanning TOF rangefinder and $4 \mu \mathrm{m}$ radiometer, window purging and cleaning subsystem, and remote signal processing, power supply and control module (fig. 3). Scan patterns can be pre-programmed to access any part of the furnace, thus allowing the entire burden profile to be monitored. The accuracy of the sensor is of the order of $\pm 50 \mathrm{~mm}$, allowing accurate measurement of dynamic angles of repose, wall profile and burden descent rate distribution. Many of the physical parameters used in the NSC-developed burden distribution model, RABIT (1), may be verified under actual blast furnace operating conditions using these data. Using the BHPdeveloped SONDE model (2) (3) and information from the RABIT model, a prediction of the shape and position of the cohesive zone may be made.

\section{Raceway sensor.}

The raceway sensor system consists of up to four heads connected via optical fibres to a laser transmission and detection unit, which is in turn connected to a second unit for control, power and signal processing (fig. 4). The sensor head is attached to a window assembly with a quick release mechanism, the window assembly being attached to the tuyere bootcap using a metal slide. The window assembly consists of the window itself, a shut-off valve, gas purging connections and an alignment mechanism. The aperture is $50 \mathrm{~mm}$ diameter.

A relative temperature measurement of the raceway is obtained using a simple brightness meter. As the raceway brightness is measured in two spectral regions simultaneously, the ratio of these two measurements gives a relative temperature. A fast-shuttered video camera, mounted inside the raceway sensor head, monitors raceway phenomena such as the movement of coke particles and the presence of unreduced ore in the raceway.

The processing of raceway sensor data is quite complex as a significant proportion of the laser radiation transmitted into the raceway will be scattered by coke particles moving within the raceway. Since the laser radiation penetrates through to various points in the raceway including the back of the raceway, the spread of range data must be processed to extract the raceway depth information. From laboratory experiments and plant trials, it was found that 100 consecutive laser pulses are sufficient for the removal of fluctuations arising from moving coke particles in the raceway (4). Therefore, in the current mode of operation, a raceway depth is measured every 100 shots, or for a laser repetition rate of $10 \mathrm{~Hz}$, a depth measurement is obtained every $10 \mathrm{~s}$. 


\section{LASER PROFILER INFORMATION : UTILISATION AND INTERPRETATION}

The high level of accuracy of the laser profiler permits the fine tuning of burden and gas distribution predictive models such as the RABIT and SONDE models, both of which are used by operators at each of the three BHP Steel steel-

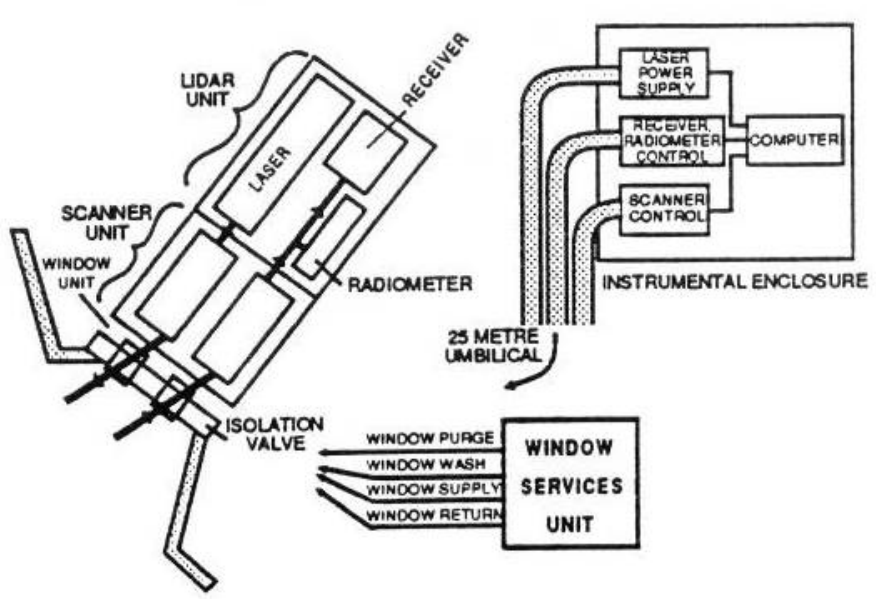

Fig. 3 - Schematic diagram of burden surface profiler.

Fig. 3 - Schéma du profilomètre laser.

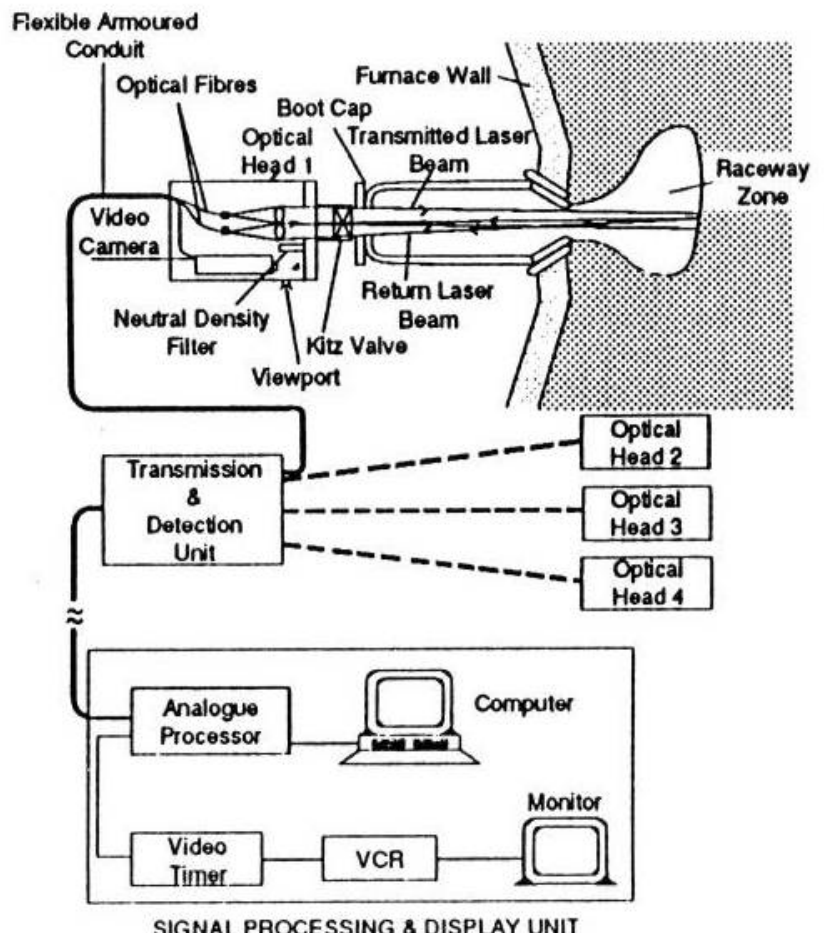

Fig. 4 - Schematic of raceway sensor.

Fig. 4 - Schéma de la sonde de zone tourbillonnaire. plants in their decision making processes. Figure $5 a$ shows the ore profile measured using the laser profiler, plotted against profiles predicted by the RABIT model for NBF4. Although the profile prediction using a superior model formulation (Version 2) compares more favourably than the other (Version 1), neither compares well with the measured profile near to the wall. In this particular case, the explanation is that the actual trajectory of the burden material has changed, possibly due to the wearing of the Paul Wurth chute refractory lining. By adjusting the trajectory parameters accordingly, i.e. considering the effect of chute wear on trajectory, the prediction is vastly improved (fig. $5 b$ ). In fact, when a coke profile measured on the same day is compared with predicted profiles using adjusted trajectory parameters (fig. $5 c$ ), this is corroborated.

The changes to the burden trajectory described above, will significantly affect the ore-to-coke distribution and therefore, gas distribution in the furnace. The effect of a trajectory correction on the cohesive zone shape can be estimated using the SONDE model, which is a two-dimensional numerical model solving for the coupled gas and solids flow, heat transfer and various chemical reactions occurring inside the furnace (2) (3).

Figure 6 shows the SONDE model predictions for the solids isotherms (solid lines) and gas velocity vectors (arrows), based on (a) the old trajectory parameters and (b) the revised trajectory parameters. In figure 6 , the cohesive zone is defined as the region between the $1200{ }^{\circ} \mathrm{C}$ and $1400{ }^{\circ} \mathrm{C}$ isotherms. Clearly, the two results differ significantly. For (a) above, the model predicts an inverted-V shape cohesive zone, with a strong central gas flow evident. For (b) above, the model predicts a W-shaped cohesive zone, with a significantly higher wall flow in the lower zone of the furnace. Thus, it is imperative that burden parameters such as burden trajectories be re-evaluated regularly so that operators have the best information available to support operating changes for short and long term control, the former to achieve hot metal quality specifications and the latter for campaign life extension.

\section{RACEWAY SENSOR INFORMATION : UTILISATION AND INTERPRETATION}

\section{Validation of raceway depth measurement.}

The raceway sensor has been used at BHP Steel's blast furnaces for a number of years, mainly as an investigative tool for determining the condition of the furnace via raceway depth, relative temperature and visual information. In most of the trials carried out, four sensor heads have been utilised and this has allowed the investigation of the peripheral distribution of gas flow in the furnace. Of particular interest is the work carried out to investigate the effect of taphole location relative to the hot blast entry main. This will be discussed below. 

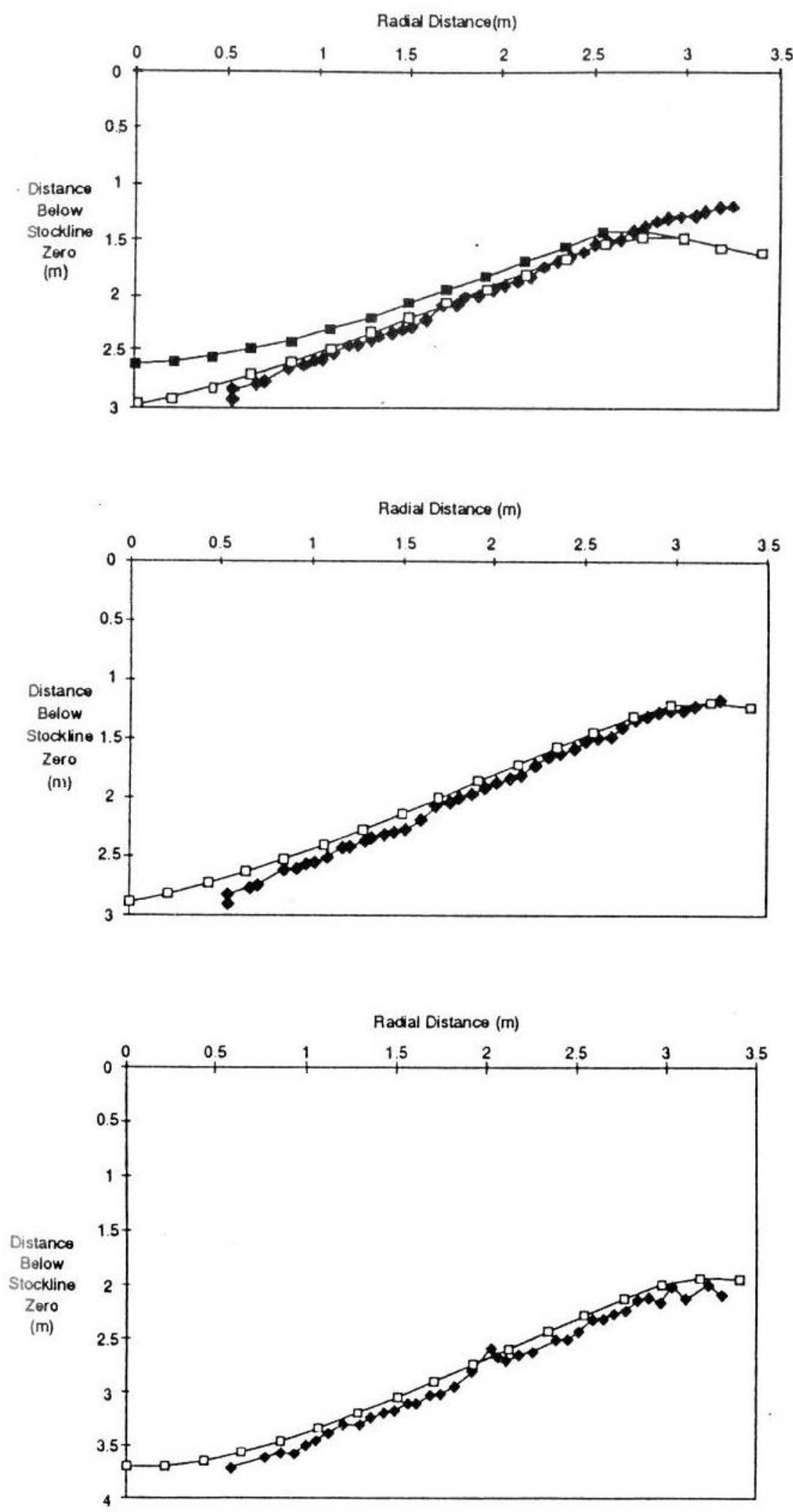

Fig. $5 a$

\section{ORE}

Laser profiler (measured)

- Model prediction (Version 1)

Model prediction (Version 2)
Fig. 5b

\section{ORE}

Laser profiler (measured)

Model prediction (Version 2, improved trajectory parameters)

Fig. 5 - Comparison between laser profiler measurement and model predictions.

Fig. 5 - Comparaison entre les mesures du profilomètre laser et les prévisions du modèle.

The validity of the raceway depth measurements has been investigated via laboratory work using a cold model of the raceway (4) and by comparing the optical measurements with those obtained using a mechanical probe inserted into the raceway of NBF4 (5). Figure 7 shows the results from the trial carried out at NBF4, where raceway depths mea- 


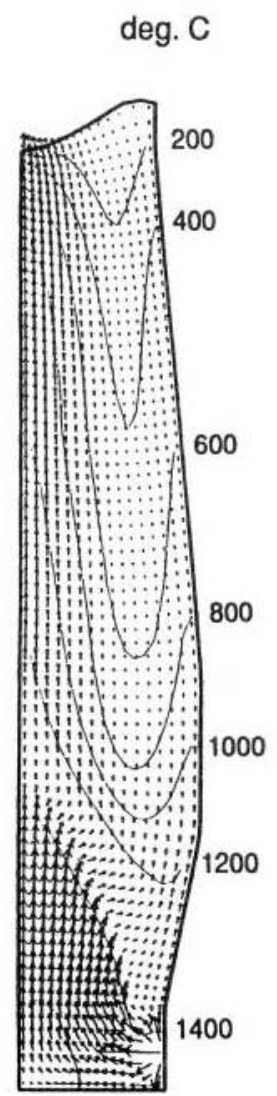

(a)

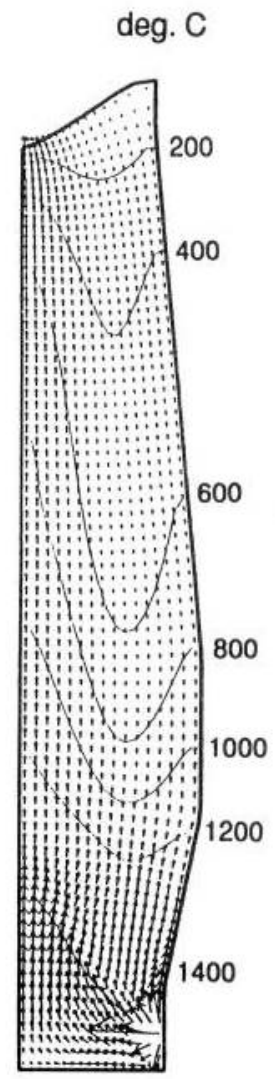

(b)
Fig. 6 - Effect of modifying trajectory parameters on SONDE model predictions of the cohesive zone and gas flow distribution. (a) Old trajectory parameters. (b) Revised trajectory parameters.

Fig. 6 - Effet de la modification des paramètres de trajectoire sur les prévisions du modèle SONDE sur la zone de fusion et la répartition du débit de gaz.

(a) Paramètres de l'ancienne trajectoire.

(b) Paramètres de la trajectoire révisée.

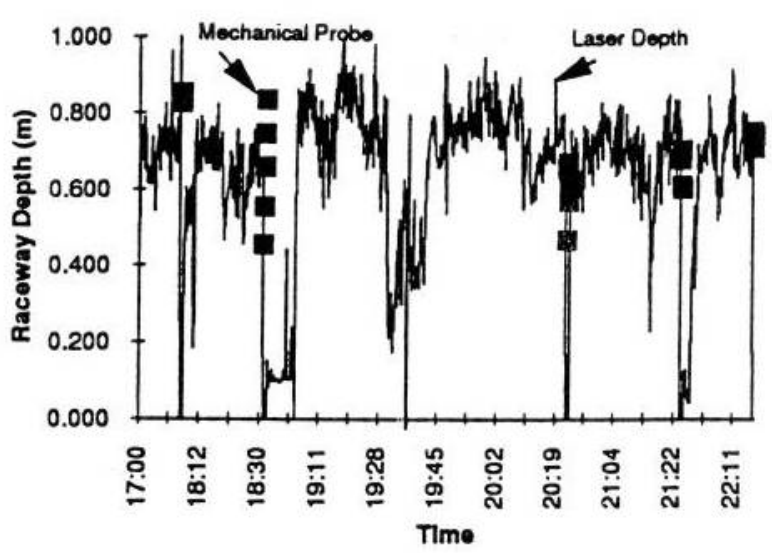

Flg. 7 - Mechanical probe validation of raceway sensor carried out at Newcastle No. 4 blast furnace.

Fig. 7 - Validation de la sonde mécanique du capteur de zone tourbillonnaire exécutée sur le haut-fourneau $n^{\circ} 4$ de Newcastle. sured by the sensor were compared with those measured using a specially designed mechanical probe. The probe was inserted a number of times through one of the furnace tuyeres during normal operations. A quick releasing valve enabled the raceway sensor to be removed and the probe to be inserted within a five minute time frame, thus reducing the uncertainty associated with variable raceway depths. Clearly, both the raceway sensor and mechanical probe measure similar raceway depths, ranging between 0.45 $1.0 \mathrm{~m}$. Interestingly, for the furnace operating conditions during the trial, the raceway depth calculated using the Hatano equation (6) is $1.1 \mathrm{~m}$. The fluctuations in depth measured by the raceway sensor were also measured using the mechanical probe. Further work is required to determine why these fluctuations occur but it is thought that charging the furnace may affect the force balance around the raceway or the dropping of unmelted ore into the raceway, as reported by Soga et al. (7).

\section{Peripheral non-uniformity of gas flow.}

Having established that the raceway sensor gave meaningful and reliable depth information, the first application of the sensor was the investigation of non-uniform gas flow at NBF4. Figure 8 shows a schematic of the furnace layout. indicating the location of the hot blast entry main relative to the two tapholes. For this furnace arrangement, the distribution of hot blast flow is significantly affected by the casting operation viz.. since the average hearth liquids level is lower on the taphole side, the overall permeability of the lower zone and therefore the blast flow should be higher.

Since the tuyere diameters were the same around the furnace and the raceway depth is strongly dependent on the blast velocity (for a constant blast temperature), the raceway depth should be indicative of the blast flow distribution. The results showed that the actual raceway depths measured on the taphole side of the furnace are much greater than those measured on the blast entry side, the average depths being approximately $1.1 \mathrm{~m}$ compared to $0.7 \mathrm{~m}$. respectively. Using the Hatano equation, the calculated

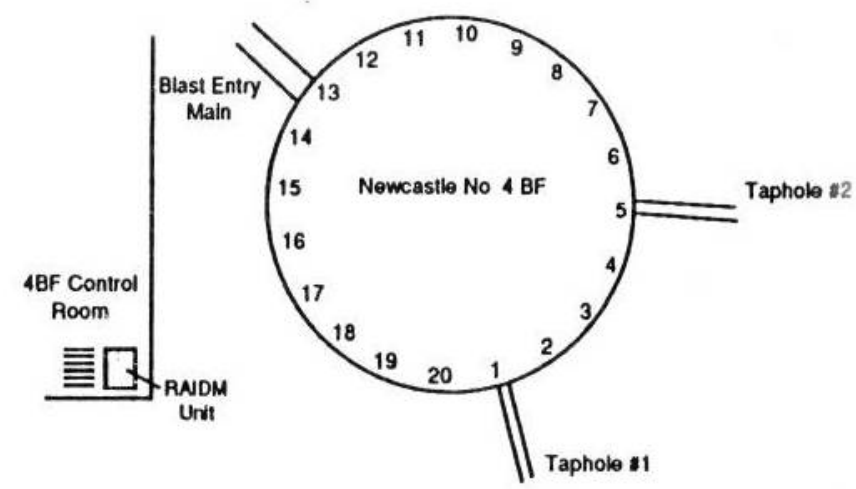

Fig. 8 - Layout of Newcastle No. 4 blast furnace.

Fig. 8 - Disposition du haut-fourneau $n^{\circ} 4$ de Newcastle. 
raceway depth for the operating conditions during the trial is $1.1 \mathrm{~m}$.

This information is significant because of its implications to the campaign life of NBF4. Based on laser profiler scans of the burden surface, the burden distribution is known to be peripherally uniform. Conversely, stave and above burden temperature information implied that both the gas distribution and cohesive zone are non-uniform, i.e. the cohesive zone is an inverted-V shape on the taphole side and W-shaped on the blast entry side. Based partly on information from both the burden profiler and raceway sensors, it became clear that one of the key actions for extending the life of this furnace was to install hot blast flow valves to control blast flow around the furnace. These valves are to be installed on NBF4 in 1994.

\section{Pulverised coal injection.}

An extension of the raceway sensing studies to pulverised coal injection (PCI) was carried out last year at Nakayama's No. 2 blast furnace in Japan. Results from this trial have been reported elsewhere (5) so only a review of the major results will be presented. It is worth noting that all BHP Steel blast furnaces operate with natural gas injection and the Nakayama trial was carried out as part of a BHP Newcastle-Nakayama Steel Technical Agreement.

The aims of the Nakayama trial were to determine the feasibility of the raceway sensor for monitoring PCI and to provide information regarding $\mathrm{PC}$ combustion under a range of blast furnace conditions. The trial consisted of measuring the range both into and around the PCI plume and also measuring the back wall of the raceway with $\mathrm{PCI}$ turned off for five minute periods. For each set of blast/PCI condition, the following measurements were recorded :

- the maximum and minimum ranges over time for a given position on the PCI plume,

- the maximum and minimum ranges over time for PCI turned off,

- the range statistics as a function of position on the plume.

Figure 9 shows the locations of the laser spot in relation to the tuyere, lance and PCI plume. The diameter of the laser pulse for these tests was constant at $40 \mathrm{~mm}$. It should be noted that Positions 1 and 4 were always outside the PCI cloud, whereas Positions 2 and 3 were targeted at the cloud. Also, note that Position 2 is on the edge of the cloud.

For this trial, a three head raceway system was used, the heads being spaced approximately 90 degrees apart and away from the taphole region. The following tests were undertaken (n.b. only the first and the third below will be discussed in detail):

- depth measurements (including raceway depths) under normal operating conditions,

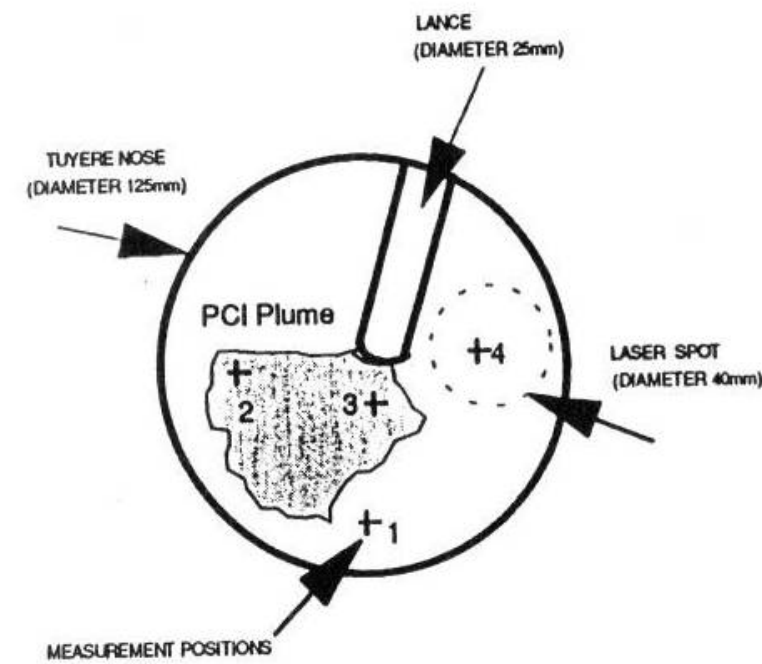

Fig. 9 - Range positions relative to the tuyere nose and $\mathrm{PCl}$ lance.

Fig. 9 - Choix des positions par rapport au nez de la tuyère et à la lance d'injection de charbon.

- depth measurements (including raceway depths) over extended periods,

- raceway characteristics with variable PCI rate,

- raceway characteristics with variable oxygen rate,

- raceway characteristics with variable blast temperature.

Figure 10 shows the variation in maximum and minimum ranges into the raceway for several target positions, with $\mathrm{PCI}$ on and off. The variation of relative total blast volume over this time is also given. Note that the zero distance is the front of the tuyere nose. With PCI on and the target set at Position 2, the range is negative, with virtually no pene-

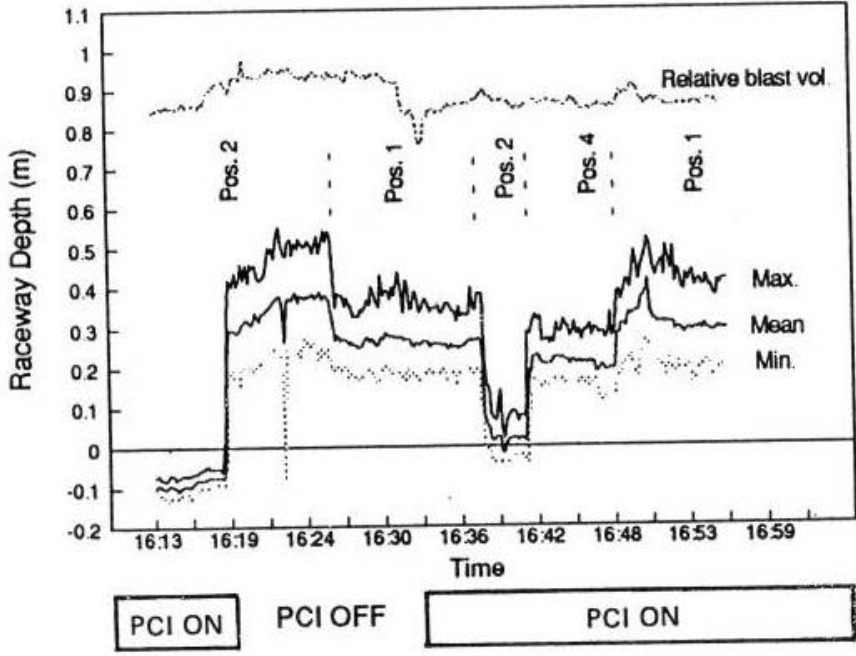

Fig. 10 - Maximum (depth) ad minimum ranges for different aiming positions, for $\mathrm{PCl}$ on and off.

Fig. 10 -Profondeurs maximales et minimales pour différentes positions de visée avec et sans injection de charbon. 
tration of the laser through the cloud. When the PCI is turned off, the maximum depth increases quickly to about. $0.4 \mathrm{~m}$ and then steadily rises over time to approximately $0.55 \mathrm{~m}$. Since both the depth and blast volume increase, it is possible that the permeability of the coke bed behind the raceway has increased.

With PCI still off and the target switched to Position 1, the maximum depth is reduced; however, a typical maximum/minimum spread for the range is retained. Although the blast volume has decreased with PCI on, the range measurement is unaffected at Position 1. Due to either a different laser spot position or varying combustion conditions, it is found that the maximum/minimum range is wider than previously measured at Position 2.

At Position 4, the laser penetrates to the back of the raceway. Note that the depth is slightly less than at Position 1, this phenomenon being observed not only at Nakayama but also on BHP Steel furnaces. Finally, with the target back at Position 1 , the raceway depth is initially longer than previously measured but soon restabilises to a similar level.

Some very interesting data were also obtained during the tests when the PCI was suddenly turned off. Figure 11 shows the speed of raceway depth recovery for different PCI rates (i.e. 300,450 and $600 \mathrm{~kg} / \mathrm{hr}$ per tuyere), with every laser shot being plotted over a $60 \mathrm{~s}$ period. The information indicates that at the higher PCI rates, the speed of response is faster while the stable raceway depth appears to be longer.

Two alternative explanations may be postulated. Firstly, as the bed is less permeable at the higher PCI rates, it is therefore more difficult for the gas to flow through it and hence, the consumption of unburnt coal and char is higher. Alternatively, since the PCI rate for the Nakayama system is changed by varying the pressure in the PC injection vessel, the plume has a higher velocity and therefore should be narrower and less diffuse at the higher rates. Additional testwork is required to determine the cause of this phenomenon.

In summary, the PCI testwork reported in this paper and in (5), indicated that it was not only possible to monitor raceway depth with $\mathrm{PCI}$ on, but also that information relating to the combustion of $\mathrm{PC}$ in the blast furnace raceway could be obtained. The logical extension of this work to an investigation of PC combustion with oxy-coal burners is being considered.

\section{Blow-in of BHP Port Kembla No. 4 blast furnace.}

Recently, the raceway sensor was used during the blow-in of BHP Port Kembla No. 4 blast furnace (PKBF4). The rationale was that for each new tuyere opened during the startup, stabilisation of the raceway depth and brightness ratio

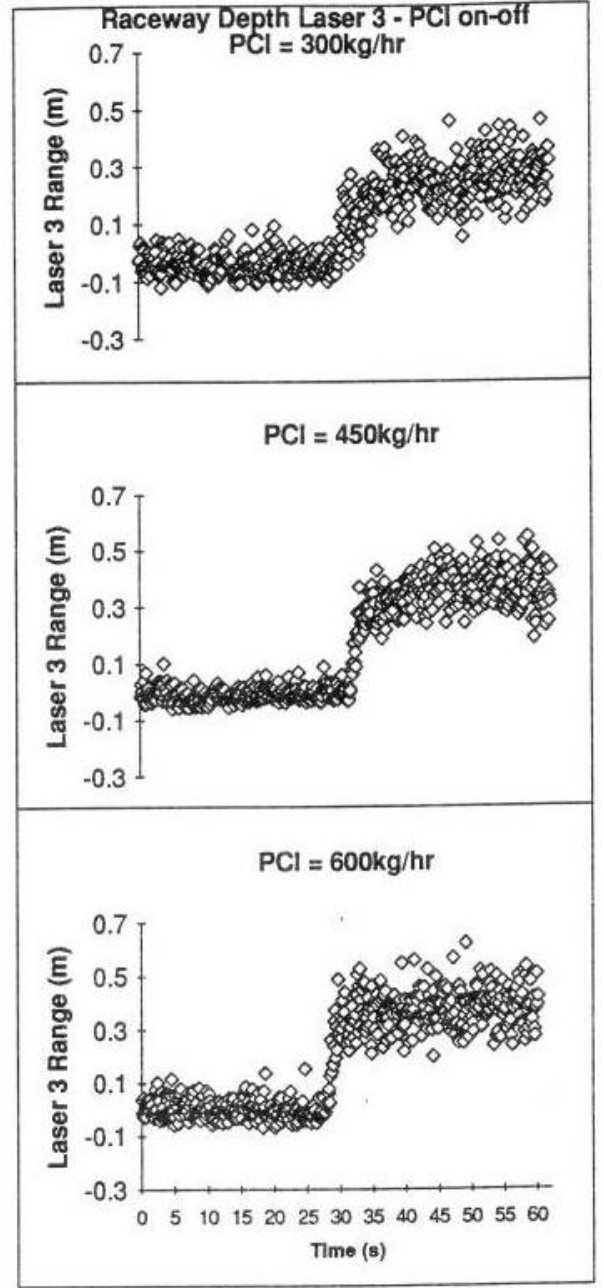

Fig. 11 - Speed of raceway depth recovery for different $\mathrm{PCl}$ rates : 300, 450 and $600 \mathrm{~kg}$ per hour.

Fig. 11 - Vitesse de retour à la profondeur de la zone tourbillonnaire pour différents taux d'injection de charbon : 300,450 et $600 \mathrm{~kg} / \mathrm{h}$.

(relative temperature), should occur at some point in time. Thus, when a stable and acceptable raceway depth and/or brightness ratio was reached, a decision whether to open the adjacent tuyere could be made. Additionally, the sensory measurements could potentially avoid opening the tuyeres too early and in particular, the video images from the fast-shuttered camera could provide visual confirmation that tuyere conditions were stable.

Figure 12 shows the layout of $\mathrm{PK} 4 \mathrm{BF}$, the special point to note here is the location of tuyeres 7 and 18 relative to the tapholes and blast entry main. Tuyere 7 is opposite the blast entry main, while tuyere 18 is almost directly below it. Both are located approximately 90 degrees to the tapholes.

Table I shows the evolution in raceway depth shortly after opening tuyeres 7 and 18. The information for tuyere 7 is typical for a tuyere not reaching stabilisation. The average maximum depth increases over the entire 10 hours after 


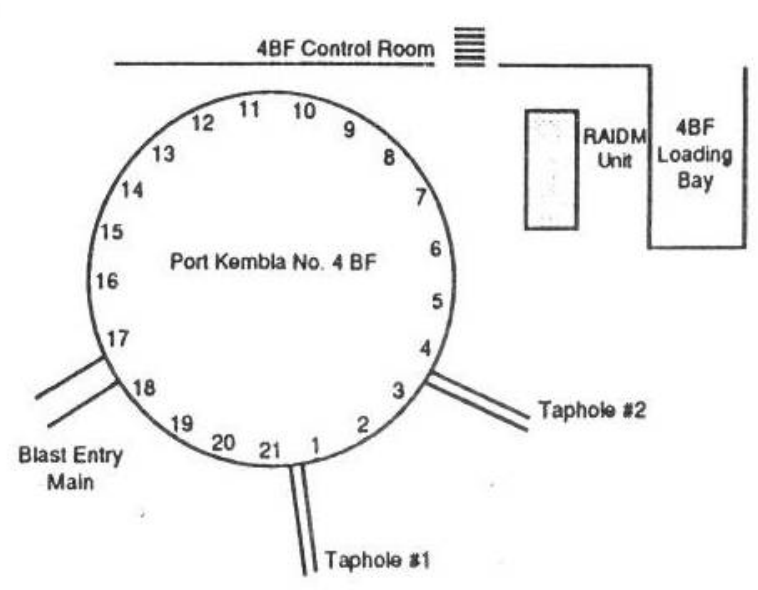

Fig. 12 - Layout of Port Kembla No. 4 blast furnace.

Fig. 12 - Disposition du haut-fourneau $n^{\circ} 4$ de Port Kembla.

opening, from $0.46 \mathrm{~m}$ at $2 \mathrm{~h}$ to $0.83 \mathrm{~m}$ after $10 \mathrm{~h}$. Between $7-8 \mathrm{~h}$ after opening the tuyere, the burden movement was quite erratic and many slips occurred during this time. In contrast, tuyere 18 reaches a stable depth soon after opening. At $2 \mathrm{~h}$, the average maximum depth measured is $0.45 \mathrm{~m}$ and changes only slightly over the next $8 \mathrm{~h}$.

With respect to the results in table $I$, two interesting points may be made. Firstly, the difference in average depths measured on tuyeres 7 and 18 are consistent with those measured at NBF4, where longer depths were found on the opposite side of the blast entry main. Secondly, the fluctuations in raceway depth are always less on the blast entry side, this being attributable to the reduced effects of hearth drainage on the measured raceway depths (5).

During the PK4BF blow-in, one of the operational objectives was to maintain stable burden movement. However, slips occurred during the blow-in, with most being monitored by the raceway sensor. Of particular interest was that the slips were predicted by the brightness meter some 5$10 \mathrm{~min}$ prior to their occurrence.

Figure 13 shows the brightness ratio trace for tuyeres 6 and 7. together with the measured total blast volume. At 15:18, the blast volume begins to increase gradually until 15:40,

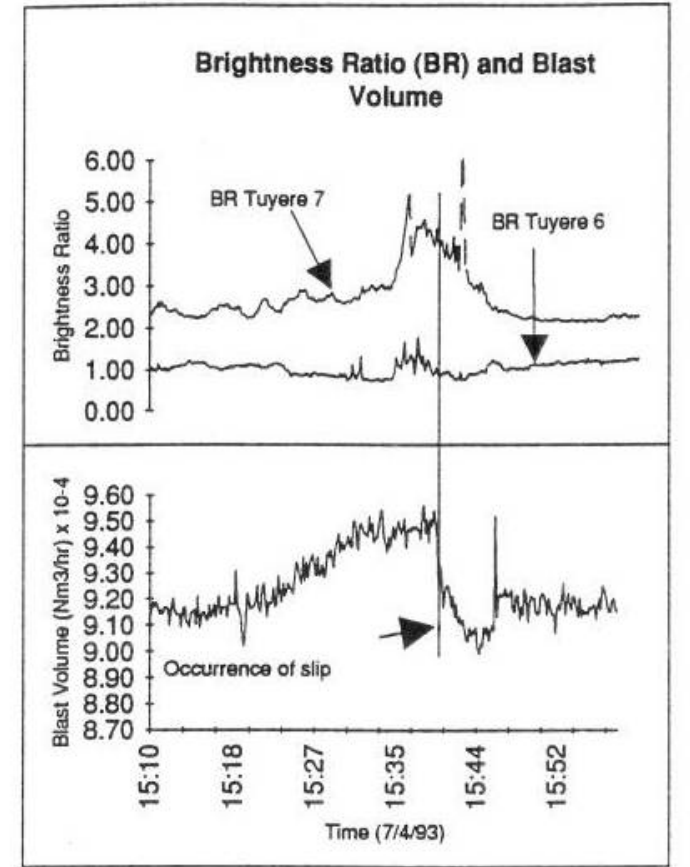

Fig. 13 - Observation of slips with brightness meter.

Fig. 13 - Observation des chutes en marche avec l'appareil de mesure de brillance.

where there is a sharp drop in flow. It is at this point that the slip occurs, as verified by stockrod movement. Referring to the upper graph in figure 13, at 15:34 (i.e. $6 \mathrm{~min}$ before the slip occurs), the brightness ratio for tuyere 7 increases quite sharply, with a similar trend observed for tuyere 6 . The differences in signal amplitude results from differences in calibration of the brightness meters and is not an indication of the extent of the slip. Following the slip and as the blast volume restabilises, the brightness ratio returns quite slowly back to a pre-slip level.

The information shown in figure 13 is consistent with our current knowledge of the slip phenomenon. Although the raceway depth measurements gave no prior indication of the onset of a slip, it was observed that before a slip (such as the slip described in figure 13), the depth measurement became erratic and decreased. Following the slip, the depth was generally shorter.

Table I : Raceway stabilisation.

Tableau I: Stabilisation de la zone tourbillonnaire.

\begin{tabular}{|c|c|c|c|c|c|c|c|}
\hline \multicolumn{7}{|c|}{ Average raceway depth (m) } \\
\hline Tuyere No. & $0 \mathrm{hr}$ & $2 \mathrm{hrs}$ & $4 \mathrm{hrs}$ & $6 \mathrm{hrs}$ & $8 \mathrm{hrs}$ & $10 \mathrm{hrs}$ & $12 \mathrm{hrs}$ \\
\hline 7 & 0.0 & 0.46 & 0.57 & 0.84 & 0.83 & 1.11 & 0.65 \\
\hline 18 & 0.0 & 0.44 & 0.54 & 0.41 & 0.39 & 0.46 & 0.38 \\
\hline
\end{tabular}




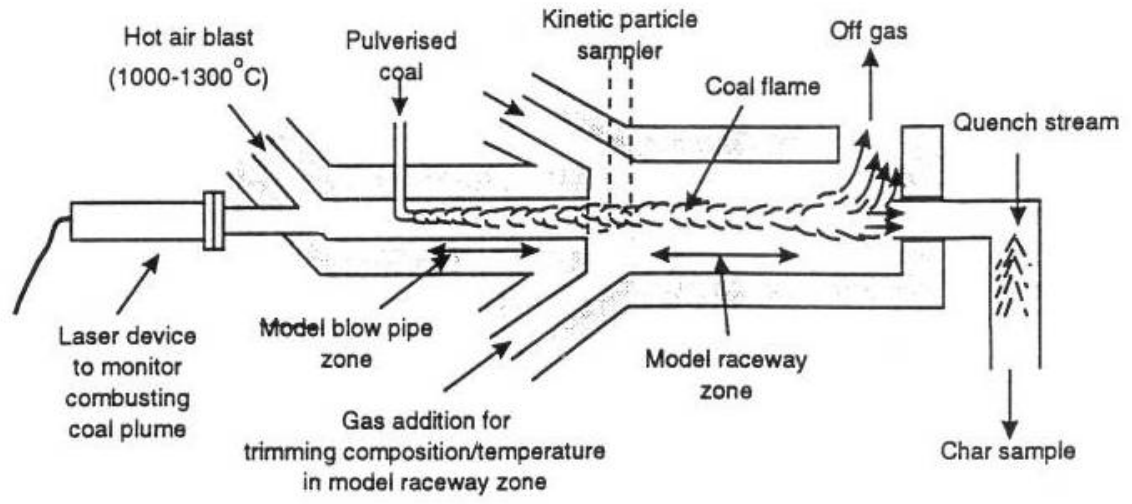

Fig. 14 - Schematic of PC combustor and raceway rig for laboratory-scale experiments at high $\mathrm{PCl}$ rates, showing position

of laser raceway sensor.

Fig. 14 - Schéma de l'équipement du brûleur de charbon injecté et de la zone tourbillonnaire pour des essais à l'échelle du laboratoire avec des taux élevés d'injection de charbon, montrant la position du capteur laser de zone tourbillonnaire.
The prediction of a slip provides the operator with the opportunity to make adjustments to blast parameters such as blast volume, thereby reducing the impact of erratic burden movement on furnace operations. This type of information may also provide a coupling between burden movement and or burden distribution at the top of the furnace and the corrective changes to tuyere parameters necessary to ensure stable furnace operations.

\section{Future work.}

One of the most important ongoing applications of the raceway sensors is in the study of pulverised coal combustion (PCC), particularly within the actual raceway. However, in order to understand fully the sensory data obtained from trials such as those conducted at Nakayama Steel, BHP Research has re-commenced a laboratory-scale PCI program, wherein the raceway sensor will be attached to the end of a combustion rig as shown figure 14. Some modifications will be made to the sensor hardware to reduce the size of the laser spot, thereby permitting a more detailed study of the PC plume and surrounding area. Under these controlled conditions, it is expected that the behaviour of various coal types under variable operating conditions (oxygen, blast temperature and PCI rates up to $300 \mathrm{~kg}$ per tonne of hot metal) will be examined.

\section{- CONCLUSIONS}

The development of laser-based sensing equipment at BHP has proven extremely useful in many areas of blast furnace operation, including burden surface profiling, pulverised coal injection and furnace blow-ins. The information obtained has been shown to be readily utilised by furnace process models and operators. With respect to the raceway sensor, there are currently two ongoing studies. First, at NBF4, the sensor is to be used to monitor furnace condi- tions prior to and following the installation of Hot Blast Flow Control Valves. Second, laboratory experiments will be carried out to assess the capabilities of the sensor for measuring the characteristics of pulverised coal injection at rates up to $300 \mathrm{~kg}$ per tonne of hot metal.

\section{REFERENCES}

(1) OKUNO (Y.), KUNIMOTO (K.), MATSUZAKI (S.), MATSUI (M.), SUZAWA (A.), Development of a mathematical model for burden distribution in a blast furnace, Proc. Ironmaking Conference, Iron and Steel Society, AIME, Vol. 44 (1985), p. 543.

(2) TANZIL (W.B.U.), MELLOR (D.G.), BURGESS (J.M.), Application of a two-dimensional flow, heat transfer and chemical reaction model for process guidance and gas distribution control on Port Kembla No. 5 blast furnace. Proc. 6th International Iron and Steel Congress, Ironmaking, Vol. 2, ISIJ, Nagoya (1990), p. 355.

(3) ZULLI (P.), REX (A.J.). Maintaining blast furnace stability and product quality using a numerical model to predict the effect of significant changes in operating conditions. Proc. Australasian Chemical Engineering Conf., CHEMECA 91. p. 468 .

(4) DUVAL (A.B.), SCOTT (J.C.), WALL (P.C.), BURGESS (J.M.). Optical sensing in the blast furnace raceway zone. Proc. 6th International Iron and Steel Congress, Ironmaking, Vol. 2, ISIJ, Nagoya (1990), p. 405.

(5) PATON (A.T.), WALL (P.C.), HUGHES (M.), Laser radar systems in the blast furnace, Proc. Ironmaking Conference. Iron and Steel Society, AIME, Vol. 52 (1993), p. 571.

(6) HATANO (M.), KURITA (K.), TANAKA (T.). Proc. International Blast Furnace Hearth and Raceway Symposium, AIMM, Newcastle (1981), p. 4-1.

(7) SOGA (H.), NAKAMURA (M.), SUGATA (M.). SeitetsuKenkyu, Vol. 289 (1976), p. 23. 